\title{
Genotypic and phenotypic features of the cystinosis patients from the South Eastern part of Turkey
}

\author{
Neslihan Önenli-Mungan ${ }^{1}$, Deniz Kör ${ }^{1}$, Aysun Karabay-Bayazıt ${ }^{2}$, Nurcan Cengiz ${ }^{3}$, \\ Sevgi Yavuz², Aytül Noyan³, Gülay Ceylaner", Berna Şeker-Yılmaz¹, Ali Kemal Topaloğlu, \\ Bilgin Yüksel ${ }^{1}$, Ali Anarat ${ }^{1}$ \\ Divisions of ${ }^{1}$ Pediatric Nutrition and Metabolism, and ${ }^{2}$ Pediatric Nephrology, Department of Pediatrics, Çukurova University \\ Faculty of Medicine, Division of ${ }^{3}$ Pediatric Nephrology, Department of Pediatrics, Başkent University Faculty of Medicine, \\ Adana, ${ }^{4}$ Intergen Genetic Laboratory, Ankara, Turkey. \\ E-mail: munganhno@gmail.com
}

Received: 29th February 2016, Revised: 22nd April 2016, Accepted: 10th November 2016

\begin{abstract}
SUMMARY: Önenli-Mungan N, Kör D, Karabay-Bayazıt A, Cengiz N, Yavuz S, Noyan A, Ceylaner G, Şeker-Yılmaz B, Topaloğlu AK, Yüksel B, Anarat A. Genotypic and phenotypic features of the cystinosis patients from the South Eastern part of Turkey. Turk J Pediatr 2016; 58: 362-370.

We have conducted this study for the purposes of demonstrating the spectrum of mutations and of identifying their effects on the phenotype, with a particular focus on the clinical course, prognosis and response to treatment. A total of 25 patients from 20 families, who have been treated and followed up after being diagnosed with cystinosis.

Nine patients were identified with mutations of homozygous c.451A>G, 7 patients with homozygous c.681G >A, 6 patients with homozygous c.834_842del, 2 patients with homozygous c.18_21delGACT and 1 patient with compound heterozygous for c.451A>G/c.1015G $>$ A. The c.834_842del mutation identified in six patients from four families has not been previously identified.

Progression to renal failure occurred earlier in the patients identified with the new mutation, despite treatment. Larger patient series are required to demonstrate the genotypic properties of the patients with cystinosis and their relationship with the clinical course.
\end{abstract}

Key words: CTNS, cystinosin, cystinosis, Fanconi syndrome, mutations.

Cystinosis is an autosomal recessive disease that can affect many tissues and organs, though it primarily invades the kidneys. It is characterized by the accumulation of an amino acid called cystine in all the lysosomes of the body due to the deficiency of cystinosin, the lysosomal membrane cystine transporter protein $^{1}$. The disease has three clinical types, depending on the age of onset and the grade of the disease: the nephropathic or classical infantile cystinosis, the late-onset juvenile or adolescent nephropathic cystinosis and the ocular nonnephropathic cystinosis. The incidence rate of nephropathic or classical infantile cystinosis is estimated to range from $1: 100000$ to $1: 200000$ in North America ${ }^{2}$. In West Brittany, France, the incidence rate is much higher (1:26000) compared to the rest of the country $(1: 320000)^{3}$. The indicating signs of renal involvement are dominant in that group, which is also the most frequent type with severe phenotype. Patients develop renal Fanconi syndrome and renal failure in the first decade of life ${ }^{4}$. Retinal changes, such as painful photophobia, may develop due to the corneal deposits in the eye, one of the other organs that is frequently affected by the disease. In those cases when the eye is affected by cystinosis, they can also be diagnosed through a renal functional evaluation, such as hypophosphatemic rickets, renal Fanconi syndrome ${ }^{5}$. The problems associated with extrarenal involvement other than the eye may include hypothyroidism and hypogonadism 
in male patients, endocrine and exocrine pancreatic insufficiency, distal myopathy, dysphagia, reduced respiratory functions and neurological complications ${ }^{2}$. The late-onset juvenile or adolescent nephropathic type may show a clinical spectrum varying from mild proximal tubulopathy to severe nephropathic syndrome ${ }^{1,6}$. Most of these patients are older than 10 years. Compared to the adult type, infantile type renal involvement is much faster ${ }^{7}$. The difference of non-nephropathic cystinosis from the other types is, that it is characterized by corneal cystine crystals and photophobia; renal involvement is not seen in this type ${ }^{7}$. Approximately $95 \%$ of cystinosis cases concern the nephropathic type ${ }^{2}$. Recently, a family has been reported to have the juvenile and ocular forms simultaneously ${ }^{8}$. This indicates that there may be transitions between the mild forms of cystinosis, and therefore, the renal function of the adult patients with cystinosis should necessarily be monitored.

It is essential to provide supportive treatments to maintain the fluid-electrolyte balance in the management and treatment of cystinosis. Early diagnosis and treatment with appropriate doses of cysteamine provide considerable reduction in the cystine level in the lysosomes, and in addition, may prevent development of renal dysfunction and extrarenal complications s, $^{90}$. They also increase the growth rate. Life-long cysteamine treatment should be maintained in order to protect the extrarenal organs following kidney transplantation. Topical eye drops with cysteamine should be used, as systemic cysteamine therapy does not have any effect on the cystine crystals accumulated in the cornea. These drops are highly effective and can completely dissolve the cystine crystals in 8 to 41 months 5 .

There are only a limited number of studies regarding the mutation spectrum of patients diagnosed with cystinosis in Turkey. In this study, we aimed to report the results of CTNS mutation analysis in 25 patients with cystinosis in a region where consanguineous marriage is more prevalent than the national average, and to present the implications of the results on the phenotype.

\section{Material and Methods}

Patients: A total of 25 patients from 20 families, who have been treated and followed after being diagnosed with cystinosis at Çukurova University Faculty of Medicine, Departments of Pediatric Metabolism and Nutrition and Pediatric Nephrology, were enrolled in the study. Informed consents were obtained from all cases (if older than 18 years obtained from patients, and if younger than 18 years from their parents).

Molecular analysis: Primers designed with PRIMER $^{\odot}$ - Primer Designer v.2.0 (Scientific \& Educational Software programme) software for all the encoding regions, exon-intron junctions and the promoter region of the CTNS gene. DNA isolation was conducted from the EDTA treated blood samples collected from the patients by using the spin column method. Sequencing reaction was performed using the automated ABI Prism 3130 GeneticAnalyser (Applied Biosystems, Inc., Foster City, Ca, ABD) capillary electrophoresis instrument for DNA sequence analysis. The sequence reaction was performed with the Big Dye Terminator cycle sequencing kit (Applied Biosystems, Inc., Foster City, Ca, US) using the forward and reverse primers, employed in the standard PCR, as primer. For this reason, the reaction mixture was prepared by diluting $2 \mu \mathrm{l}$ of purified PCR product, $3 \mu \mathrm{l}$ of big dye and $2 \mu \mathrm{l}(3.2 \mathrm{pmol} /$ ul) of primer, resulting in a total volume of $10 \mu \mathrm{l}$ with the inclusion of distilled water. The cycle sequencing process was done with the obtained mixture using the same study protocol in the PCR device, and the resulting product was purified. After, formamide was added into the product, and following denaturation at $95^{\circ} \mathrm{C}$ for 5 minutes, the product was immediately placed onto ice and allowed to stand for 2 minutes before operating the sequence device following the loading process. Loading process was done with the standard protocol given in user manual of the capillary electrophoresis device. The reference sequence obtained from the Ensembl database and the sequences from the samples examined were compared using the software developed by ABI for the comparison of DNA sequences.

Blood was collected from the patients into 10 $\mathrm{ml}$ heparin tubes to determine the leukocyte cystine level. The leukocytes were then isolated. The cystine level in the isolated leukocytes was studied using the LC-MS/MS method (Watres Acquity UPLC, Zevo TQ-S mass spectrometry, 


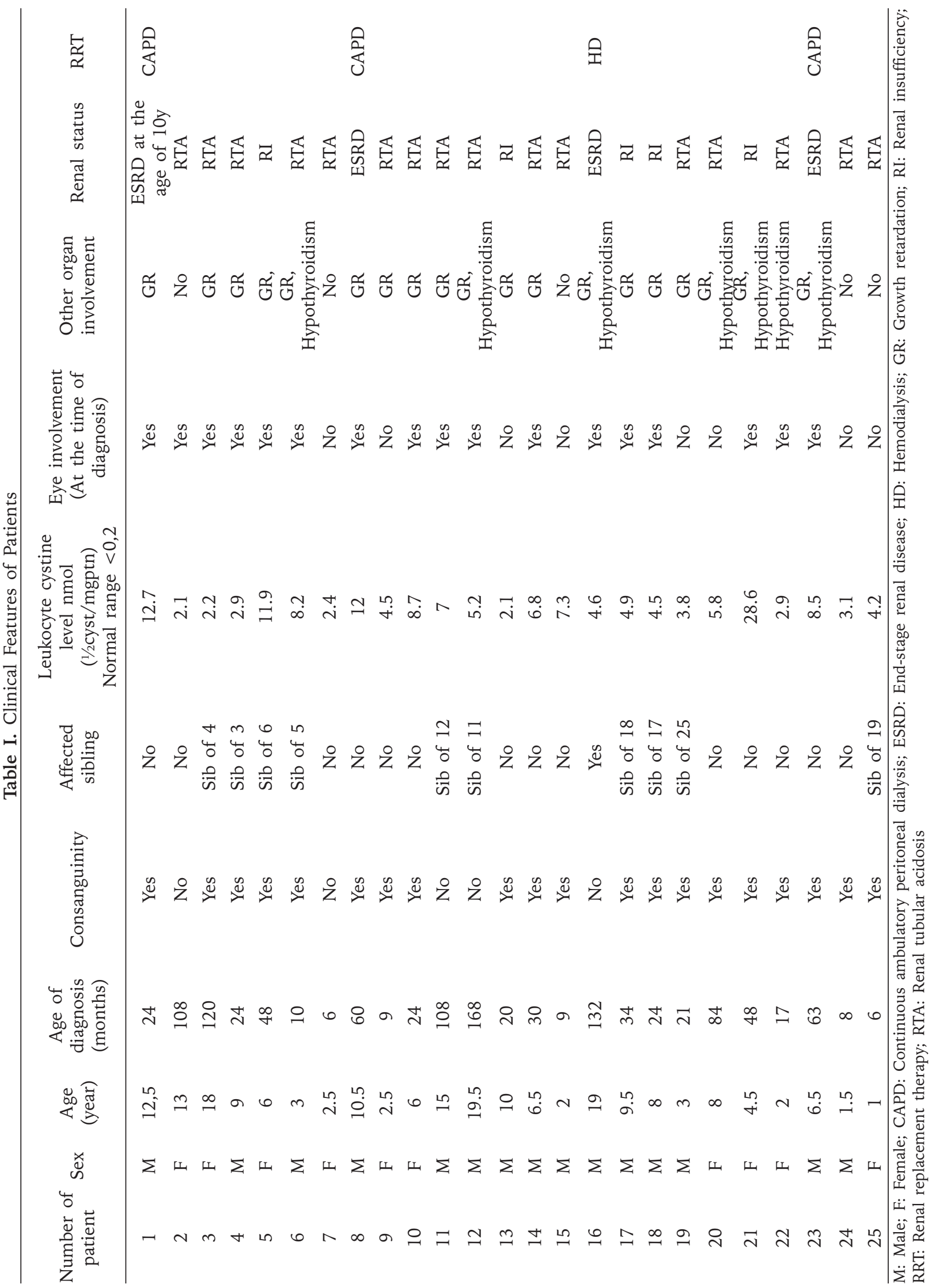


Ireland). The results were given in nmol 1/2cyst/ mgptn. In general, leukocyte cystine levels are $>2 \mathrm{nmol} 1 / 2 \mathrm{cyst} / \mathrm{mgptn}$ in affected patients, whereas normal subjects have levels $<0.2$ nmol 1/2cyst/mgptn.

\section{Results}

A total of 25 patients, 15 males and 10 females, ranging in age from 1 to 19 years, from 20 independent families were evaluated in terms of genotype and phenotype. Second degree cousin marriage was the case in 16 families, and 18 patients were from the same province. Four of these families had two affected children. The age of the patients at the time of diagnosis varied from 6 months to 14 years. All of the patients had been receiving treatment with cysteamine bitartrate (1.3-1.95 $\mathrm{g} / \mathrm{m}^{2} /$ day) at the time of the diagnosis. Three patients were receiving continuous ambulatory peritoneal dialysis (CAPD) due to the end-stage renal disease, and one patient was receiving hemodialysis twice a week. Five patients developed chronic renal disease without the need for dialysis.

All of the patients were screened for mutations in CTNS gene by sequence analysis. Mutations were given by using ENST00000046640 transcript. A total of five mutations, one of which had not previously been identified, were determined. Nine patients were identified with homozygous NM_004937.2(CTNS):c.451A > G (p. R151G) missense mutation, 7 patients with homozygous NM_004937.2(CTNS):c.681G >A splice site mutation, 6 patients with homozygous NM_004937.2(CTNS):c.834_842del mutation, 2 patient with homozygous NM_004937.2(CTNS): c.18_21delGACT (p.T7Ffs*7) frameshift mutation, and 1 patient with compound heterozygous for NM_004937.2(CTNS):c.451A>G (p. R151G) / NM_004937.2(CTNS): c.1015G >A (p.G339R) missense mutations. Allele frequency was performed on the basis of family to avoid a sampling error, as the patients $3-4,5-6,11-$ $12,17-18$ and $19-25$ were siblings. Although among 50 alleles of 25 patients, c. $451 \mathrm{~A}>\mathrm{G}$ mutation was identified in 19 alleles, c.681G $>$ A in 14 alleles, c.834 842del in 12 alleles, c.18_21delGACT in 4 alleles and c.1015G $>$ A in 1 allele, when the study evaluated one individual for each of the 20 families, c. $451 \mathrm{~A}>\mathrm{G}$
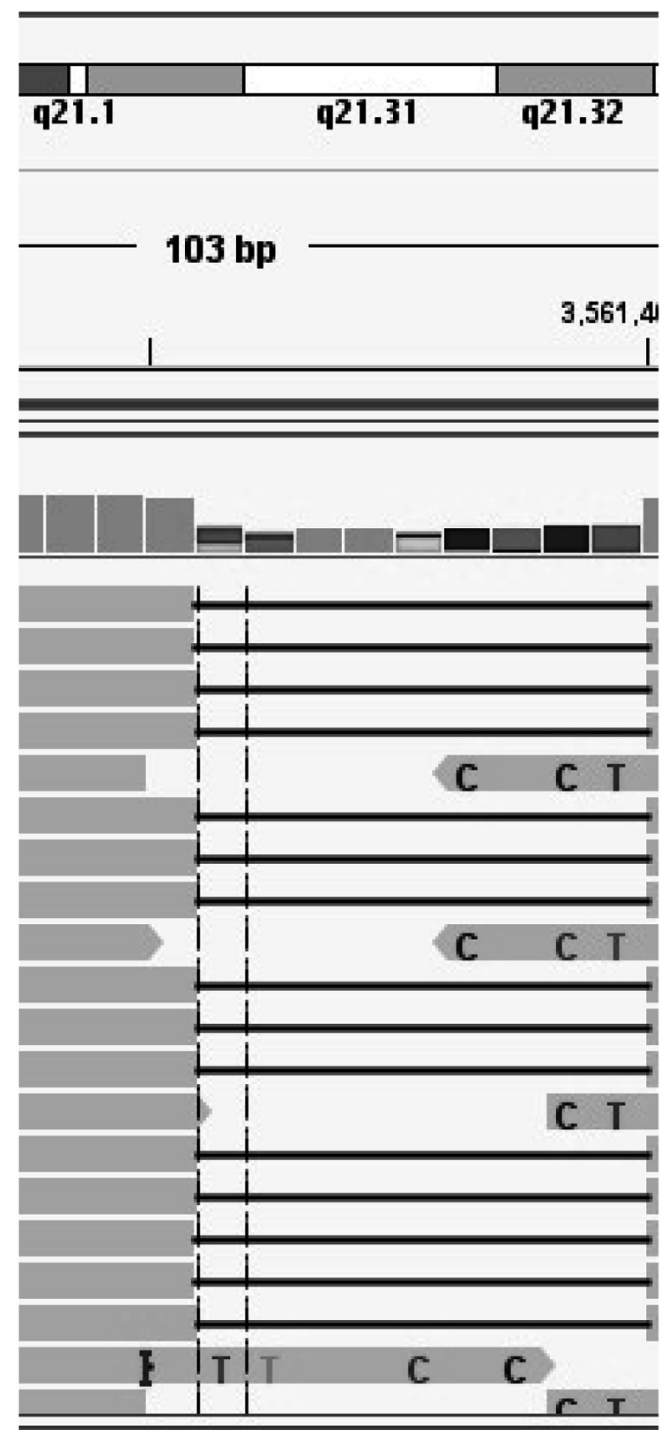

Fig. 1. Novel mutation detected in this study

mutation was identified in 15 alleles $(37,5 \%)$, c.834_842del in 8 alleles (20\%), c.681G $>$ A in 12 alleles (30\%), c.18_21delGACT in 4 alleles (10\%) and c. $1015 \bar{G}>A(2.5 \%)$ in 1 allele out of 40 alleles in the allele frequency study performed. The c.834_842del mutation identified in six patients was a mutation that had not been described before. This mutation, resulting from the homozygous 9-nucleotide deletion leading to loss of 3 amino acids in Exon 10, was determined in 4 families (Fig. $1)$. The families' pedigree are shown in figure 2. Further, 10 patients were identified with c. $451 \mathrm{~A}>\mathrm{G}$ mutation, which was described for the first time in Turkey. Table I, II, III and Table IV show the clinical characteristics of 
Table II. Mutations of the Patients (novel mutations written in bold)

\begin{tabular}{|c|c|c|c|c|c|}
\hline $\begin{array}{l}\text { Number } \\
\text { of } \\
\text { patient }\end{array}$ & Position & Base change & AA change & Reference & \\
\hline 1 & $\begin{array}{l}\text { Exon } 10 \\
\text { Exon } 10\end{array}$ & $\begin{array}{l}\text { c. } 834 \_842 \mathrm{del} \\
\text { c. } 834 \text { 842del }\end{array}$ & p.V279_Y281del & & \multirow[t]{4}{*}{$\begin{array}{l}\text { In-frame deletion the } \\
\text { loss of three amino acids }\end{array}$} \\
\hline 2 & $\begin{array}{l}\text { Exon } 7 \\
\text { Exon } 7\end{array}$ & $\begin{array}{l}\text { c. } 45 \overline{1} \mathrm{~A}>\mathrm{G} \\
\text { c. } 451 \mathrm{~A}>\mathrm{G}\end{array}$ & p.R151G & $\begin{array}{l}\text { Topaloğlu } \\
\text { et al. } 2012\end{array}$ & \\
\hline 3 & $\begin{array}{l}\text { Exon } 7 \\
\text { Exon } 7\end{array}$ & $\begin{array}{l}\text { c. } 451 A>G \\
\text { c. } 451 A>G\end{array}$ & p.R151G & $\begin{array}{l}\text { Topaloğlu } \\
\text { et al. } 2012\end{array}$ & \\
\hline 4 & $\begin{array}{l}\text { Exon } 7 \\
\text { Exon } 7\end{array}$ & $\begin{array}{l}\text { c. } 451 \mathrm{~A}>\mathrm{G} \\
\text { c. } 451 \mathrm{~A}>\mathrm{G}\end{array}$ & p.R151G & $\begin{array}{l}\text { Topaloğlu } \\
\text { et al. } 2012\end{array}$ & \\
\hline 5 & $\begin{array}{l}\text { Exon } 10 \\
\text { Exon } 10\end{array}$ & $\begin{array}{l}\text { c.834_842del } \\
\text { c.834_842del }\end{array}$ & p.V279_Y281del & & \multirow{8}{*}{$\begin{array}{l}\text { In-frame deletion the } \\
\text { loss of three amino acids } \\
\text { In-frame deletion the } \\
\text { loss of three amino acids }\end{array}$} \\
\hline 6 & $\begin{array}{l}\text { Exon } 10 \\
\text { Exon } 10\end{array}$ & $\begin{array}{l}\text { c. } 834 \_842 \mathrm{del} \\
\text { c. } 834 \_842 \mathrm{del}\end{array}$ & p.V279_Y281del & Topaloğlu & \\
\hline 7 & $\begin{array}{l}\text { Exon } 7 \\
\text { Exon } 12\end{array}$ & $\begin{array}{l}\text { c. } 451 \mathrm{~A}>\mathrm{G} \\
\text { c. } 1015 \mathrm{G}>\mathrm{A}\end{array}$ & $\begin{array}{l}\text { p.R151G } \\
\text { p.G339R }\end{array}$ & $\begin{array}{l}\text { et al. } 2012 \\
\text { Shotelersuk } \\
\text { et al. } 1998\end{array}$ & \\
\hline 8 & $\begin{array}{l}\text { Exon } 9 \\
\text { Exon } 9\end{array}$ & $\begin{array}{l}\text { c. } 681 \mathrm{G}>\mathrm{A} \\
\text { c. } 681 \mathrm{G}>\mathrm{A}\end{array}$ & p.E227E & $\begin{array}{l}\text { Aldahmesh } \\
\text { et al. } 2009\end{array}$ & \\
\hline 9 & $\begin{array}{l}\text { Exon } 9 \\
\text { Exon } 9\end{array}$ & $\begin{array}{l}\text { c. } 681 \mathrm{G}>\mathrm{A} \\
\text { c. } 681 \mathrm{G}>\mathrm{A}\end{array}$ & p.E227E & $\begin{array}{l}\text { Aldahmesh } \\
\text { et al. } 2009\end{array}$ & \\
\hline 10 & $\begin{array}{l}\text { Exon } 7 \\
\text { Exon } 7\end{array}$ & $\begin{array}{l}\text { c. } 451 \mathrm{~A}>\mathrm{G} \\
\text { c. } 451 \mathrm{~A}>\mathrm{G}\end{array}$ & p.R151G & $\begin{array}{l}\text { Topaloğlu } \\
\text { et al. } 2012\end{array}$ & \\
\hline 11 & $\begin{array}{l}\text { Exon } 7 \\
\text { Exon } 7\end{array}$ & $\begin{array}{l}\text { c. } 451 A>G \\
\text { c. } 451 A>G\end{array}$ & p.R151G & $\begin{array}{l}\text { Topaloğlu } \\
\text { et al. } 2012\end{array}$ & \\
\hline 12 & $\begin{array}{l}\text { Exon } 7 \\
\text { Exon } 7\end{array}$ & $\begin{array}{l}\text { c. } 451 \mathrm{~A}>\mathrm{G} \\
\text { c. } 451 \mathrm{~A}>\mathrm{G}\end{array}$ & p.R151G & $\begin{array}{l}\text { Topaloğlu } \\
\text { et al. } 2012\end{array}$ & \\
\hline 13 & $\begin{array}{l}\text { Exon } 10 \\
\text { Exon } 10\end{array}$ & $\begin{array}{l}\text { c.834_842del } \\
\text { c.834_842del }\end{array}$ & p.V279_Y281del & & \multirow[t]{4}{*}{$\begin{array}{l}\text { In-frame deletion the } \\
\text { loss of three amino acids }\end{array}$} \\
\hline 14 & $\begin{array}{l}\text { Exon } 7 \\
\text { Exon } 7\end{array}$ & $\begin{array}{l}\text { c. } 451 \mathrm{~A}>\mathrm{G} \\
\text { c. } 451 \mathrm{~A}>\mathrm{G}\end{array}$ & p.R151G & $\begin{array}{l}\text { Topaloğlu } \\
\text { et al. } 2012\end{array}$ & \\
\hline 15 & $\begin{array}{l}\text { Exon } 3 \\
\text { Exon } 3\end{array}$ & $\begin{array}{l}\text { c.18_21delGACT } \\
\text { c.18_21delGACT }\end{array}$ & p.T7fs & Town 1998 & \\
\hline 16 & $\begin{array}{l}\text { Exon } 7 \\
\text { Exon } 7\end{array}$ & $\begin{array}{l}\text { c. } 451 \mathrm{~A}>\mathrm{G} \\
\text { c. } 451 \mathrm{~A}>\mathrm{G}\end{array}$ & p.R151G & $\begin{array}{l}\text { Topaloğlu } \\
\text { et al. } 2012\end{array}$ & \\
\hline 17 & $\begin{array}{l}\text { Exon } 10 \\
\text { Exon } 10\end{array}$ & $\begin{array}{l}\text { c.834_842del } \\
\text { c.834_842del }\end{array}$ & p.V279_Y281del & & \multirow{9}{*}{$\begin{array}{l}\text { In-frame deletion the } \\
\text { loss of three amino acids } \\
\text { In-frame deletion the } \\
\text { loss of three amino acids }\end{array}$} \\
\hline 18 & $\begin{array}{l}\text { Exon } 10 \\
\text { Exon } 10\end{array}$ & $\begin{array}{l}\text { c.834_842del } \\
\text { c.834_842del }\end{array}$ & p.V279_Y281del & & \\
\hline 19 & $\begin{array}{l}\text { Exon } 9 \\
\text { Exon } 9\end{array}$ & $\begin{array}{l}\text { c. } 681 \mathrm{G}>\mathrm{A} \\
\text { c. } 681 \mathrm{G}>\mathrm{A}\end{array}$ & p.E227E & $\begin{array}{l}\text { Aldahmesh } \\
\text { et al. } 2009\end{array}$ & \\
\hline 20 & $\begin{array}{l}\text { Exon } 7 \\
\text { Exon } 7\end{array}$ & $\begin{array}{l}\text { c. } 451 \mathrm{~A}>\mathrm{G} \\
\text { c. } 451 \mathrm{~A}>\mathrm{G}\end{array}$ & p.R151G & $\begin{array}{l}\text { Topaloğlu } \\
\text { et al. } 2012\end{array}$ & \\
\hline 21 & $\begin{array}{l}\text { Exon } 9 \\
\text { Exon } 9\end{array}$ & $\begin{array}{l}\text { c. } 681 \mathrm{G}>\mathrm{A} \\
\text { c. } 681 \mathrm{G}>\mathrm{A}\end{array}$ & p.E227E & $\begin{array}{l}\text { Aldahmesh } \\
\text { et al. } 2009\end{array}$ & \\
\hline 22 & $\begin{array}{l}\text { Exon } 9 \\
\text { Exon } 9\end{array}$ & $\begin{array}{l}\text { c. } 681 \mathrm{G}>\mathrm{A} \\
\text { c. } 681 \mathrm{G}>\mathrm{A}\end{array}$ & p.E227E & $\begin{array}{l}\text { Aldahmesh } \\
\text { et al. } 2009\end{array}$ & \\
\hline 23 & $\begin{array}{l}\text { Exon } 9 \\
\text { Exon } 9\end{array}$ & $\begin{array}{l}\text { c. } 681 \mathrm{G}>A \\
\text { c. } 681 \mathrm{G}>\mathrm{A}\end{array}$ & p.E227E & $\begin{array}{l}\text { Aldahmesh } \\
\text { et al. } 2009\end{array}$ & \\
\hline 24 & $\begin{array}{l}\text { Exon } 3 \\
\text { Exon } 3\end{array}$ & $\begin{array}{l}\text { c.18_21delGACT } \\
\text { c.18_21delGACT }\end{array}$ & p.T7fs & Town 1998 & \\
\hline 25 & $\begin{array}{l}\text { Exon } 9 \\
\text { Exon } 9\end{array}$ & $\begin{array}{l}\text { c. } 681 \mathrm{G}>\mathrm{A} \\
\text { c. } 681 \mathrm{G}>\mathrm{A}\end{array}$ & p.E227E & $\begin{array}{l}\text { Aldahmesh } \\
\text { et al. } 2009\end{array}$ & \\
\hline
\end{tabular}


Table III. Mutation Details Detected in Our Study Group

\begin{tabular}{|c|c|c|c|c|c|}
\hline Position & Mutation & $\begin{array}{l}\text { Allele } \\
\text { frequency } \\
\quad(\%)\end{array}$ & References & $\begin{array}{l}\text { HGMD- } \\
\text { Public }\end{array}$ & Notes \\
\hline Exon 3 & $\begin{array}{l}\text { c.18_21delGACT } \\
\text { (p.T7Ffs*7) }\end{array}$ & 10 & Town 1998 & CD982561 & $\begin{array}{l}\text { Frame shift mutation causing premature } \\
\text { stop codon. Pathogenic due to Mutation } \\
\text { taster software. }\end{array}$ \\
\hline Exon 8 & $\begin{array}{l}\text { c. } 681 G>A \\
(p . E 227 E)\end{array}$ & 30 & $\begin{array}{l}\text { Aldahmesh } \\
\text { et al. } 2009\end{array}$ & & $\begin{array}{l}\text { Last nucleotide of exon } 8 \text {. Splice site } \\
\text { mutation. }\end{array}$ \\
\hline Exon 7 & $\begin{array}{l}\text { c. } 451 A>G \\
\text { (p.R151G) }\end{array}$ & 37.5 & $\begin{array}{l}\text { Topaloğlu et } \\
\text { al. } 2012\end{array}$ & CM1110321 & $\begin{array}{c}\text { Pathogenic due to Mutation taster, SIFT, } \\
\text { SIFT Provean and Polyphen prediction } \\
\text { softwares. }\end{array}$ \\
\hline Exon 10 & $\begin{array}{l}\text { c.834 } 842 \text { del } \\
\text { (p. } . \bar{V} 279 \\
\text { Y281del) }\end{array}$ & 20 & $\begin{array}{l}\text { Novel } \\
\text { Mutation }\end{array}$ & & $\begin{array}{l}\text { In-frame deletion the loss of three } \\
\text { amino acids (VKY aminoacids). K } \\
\text { and Y aminoacids is conserved in } \\
\text { different species. This deletion is on } \\
\text { transmembrain Helical domain and } \\
\text { PQ-loop 2. Mutation taster prediction: } \\
\text { Disease-causing (0.967821779118879). }\end{array}$ \\
\hline Exon 12 & $\begin{array}{l}\text { c. } 1015 G>A \\
\text { (p.G339R) }\end{array}$ & 2.5 & $\begin{array}{l}\text { Shotelersuk } \\
\text { et al. } 1998\end{array}$ & CM980461 & $\begin{array}{l}\text { rs121908127. Pathogenic due to } \\
\text { Mutation taster, SIFT, SIFT Provean and } \\
\text { Polyphen prediction softwares. }\end{array}$ \\
\hline
\end{tabular}

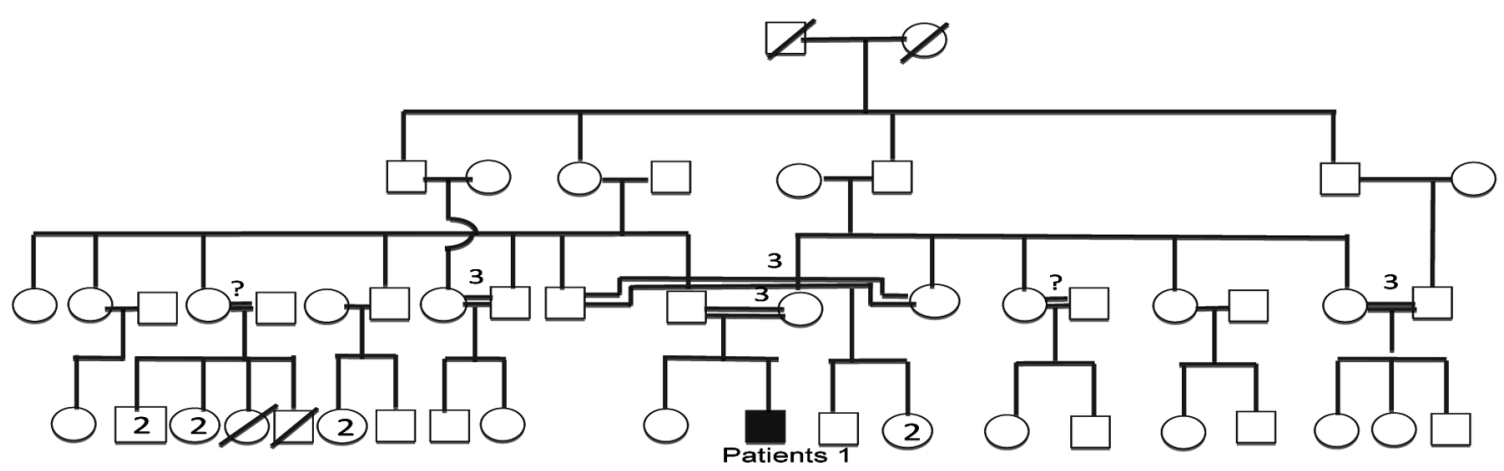

Fig. 2a. Pedigree of patient 1

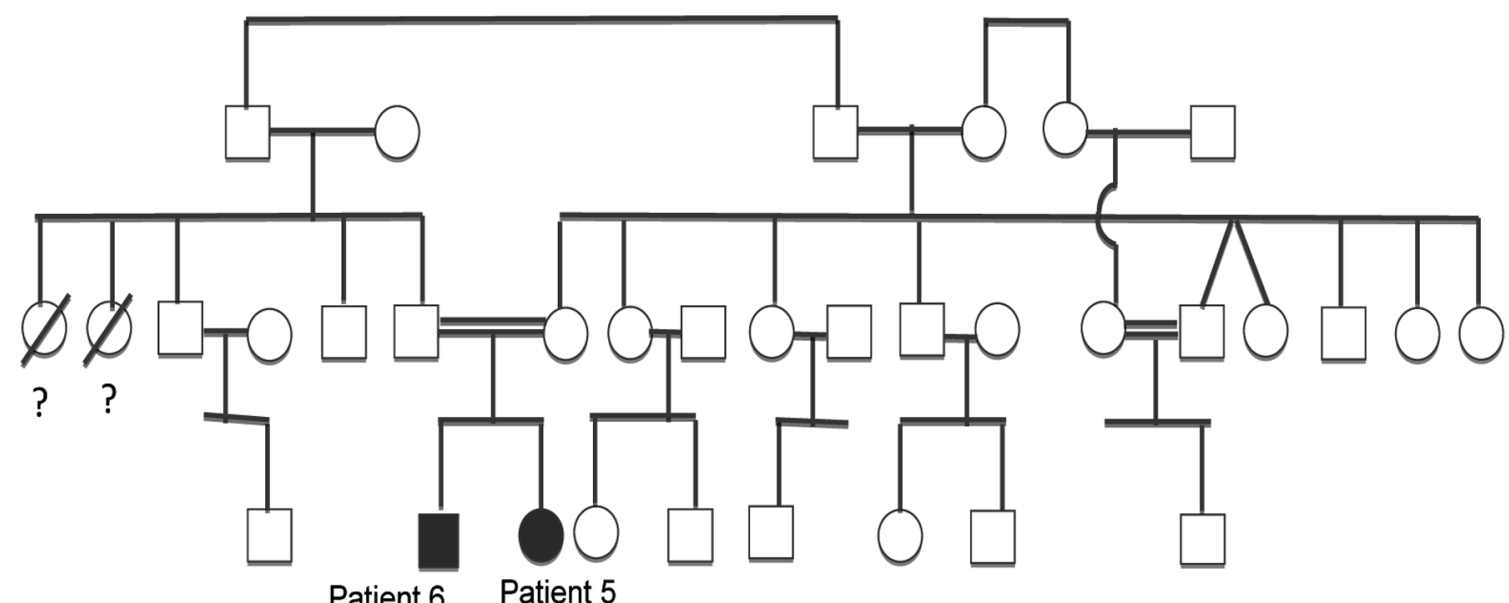

Fig. 2b. Pedigree of patients 5-6 
Table IV. Conservation Table of Mutation c.834_842del (p.V279_Y281del)

\begin{tabular}{|c|c|c|c|c|}
\hline Species & Match & Gene & AA & Alignment \\
\hline Human & & ENST00000046640 & 279 & $\begin{array}{l}\text { C F S Y I K L A V T L V K YF P Q A } \\
\text { Y M N F Y K S }\end{array}$ \\
\hline mutated & & ENST00000046640 & 279 & $\begin{array}{l}\text { C F S Y I K L A V T L - - F P Q A Y } \\
\text { M N F Y Y K }\end{array}$ \\
\hline P. troglodytes & all identical & ENSPTRG00000008572 & 254 & $\begin{array}{l}\text { C F S Y I K L A V T L V K YF P Q A } \\
\text { Y M N F Y K }\end{array}$ \\
\hline M. mulatta & all identical & ENSMMUG00000023389 & 279 & $\begin{array}{l}\text { C F S Y I K L A V T L V K YF P Q A } \\
\text { Y M N F Y K }\end{array}$ \\
\hline F. catus & all identical & ENSFCAG00000007923 & 279 & $\begin{array}{l}\text { C F S Y I K L A V T L V K YF P Q A } \\
\text { Y M N F Y Y K }\end{array}$ \\
\hline M. musculus & all conserved & ENSMUSG00000005949 & 279 & C F S Y IK L I I T L IK YF P Q A Y \\
\hline G. gallus & all conserved & ENSGALG00000004628 & 290 & $\begin{array}{l}\text { C F S Y I K L A V T L IK YF P Q A Y } \\
\text { M N F R R K }\end{array}$ \\
\hline \multicolumn{5}{|l|}{ T. rubripes } \\
\hline D. rerio & all identical & ENSDARG00000008890 & 284 & $\begin{array}{l}\text { Y F S Y I K L G V T L V K YI P Q A } \\
\text { H M N Y R R K }\end{array}$ \\
\hline D. melanogaster & all conserved & FBgn0039045 & 284 & $\begin{array}{l}\text { Y C S Y V K L T I T I IK YV P Q A L } \\
\text { M N Y R R K }\end{array}$ \\
\hline C. elegans & $\begin{array}{l}\text { partly } \\
\text { conserved }\end{array}$ & C41C4.7 & 281 & $\begin{array}{l}\text { S L S Y I K M A V T C CK YF P Q A } \\
\text { Y F N T R K }\end{array}$ \\
\hline X. tropicalis & all conserved & ENSXETG00000005795 & 289 & $\begin{array}{l}\text { C F S Y I K L A I T L IK YF P Q A Y } \\
\text { M N F R R K }\end{array}$ \\
\hline
\end{tabular}

Multiple amino acid alignment of human CTNS with other species CTNS proteins. The valine 279 tyrosine 281 residues of CTNS are marked with grey.

the patients and the results of the genetic analysis, respectively.

\section{Discussion}

In this study, we reported the molecular genetic analysis results of 25 patients with cystinosis. We have identified five different CTNS mutations, one of which had not been described before and one of which was described for the first time in Turkey. The 57$\mathrm{kb}$ deletion is the most common type, affecting the first 10 exons and the intron region of the CTNS gene, at a rate of $37 \%$ in patients with cystinosis in Europe and North America11-13. In parallel with the results obtained by Topaloğlu et al. ${ }^{14}$ in Turkey, none of the patients were identified with 57-kb deletion. Therefore, it would be safe to conclude that the patients with cystinosis in Turkey have a different mutation spectrum from those of Europe and the USA. In a study performed by Shahkarami et al. ${ }^{15}$, $57-\mathrm{kb}$ deletion could not be demonstrated in Iran, but rather, the c.681G $>$ A mutation was reported as the most common type of mutation, a discovery described by Aldahmesh et al. ${ }^{16}$ for the first time in Arabian society.
In this study the c. $451 \mathrm{~A}>\mathrm{G}$ mutation was determined in 10 patients, one of which was a compound heterozygote. c. $451 \mathrm{~A}>\mathrm{G}$ mutation was described by Topaloğlu et al. ${ }^{14}$ for the first time in 2012 in Turkey ${ }^{14}$. Having been identified in 19 out of 50 alleles (38\%) obtained from 25 patients, this mutation was the most common type in the study group. The frequency of this mutation was determined to be $37.5 \%$ in the evaluations performed on the basis of families. The c.834_842del mutation, which also had never been described in the literature, was observed in 12 out of 50 alleles (frequency of allele $24 \%$ ). This frequency was determined as $20 \%$ in the evaluation performed on the basis of families. This indicates that these two mutations, which have only been described in Turkey, are observed in $57.5 \%$ of the alleles studied in the region. The allele frequency was determined as $30 \%$ for c. $681 \mathrm{G}>\mathrm{A}$ mutation. The allele frequency of c.18_21delGACT mutation described for the first time by Town et al. ${ }^{11}$ was found as $10 \%$ in two patients, whereas the allele frequency of c.1015G $>A$ mutation, being a compound heterozygous for c. $451 \mathrm{~A}>\mathrm{G}$, described by Shotelersuk et 


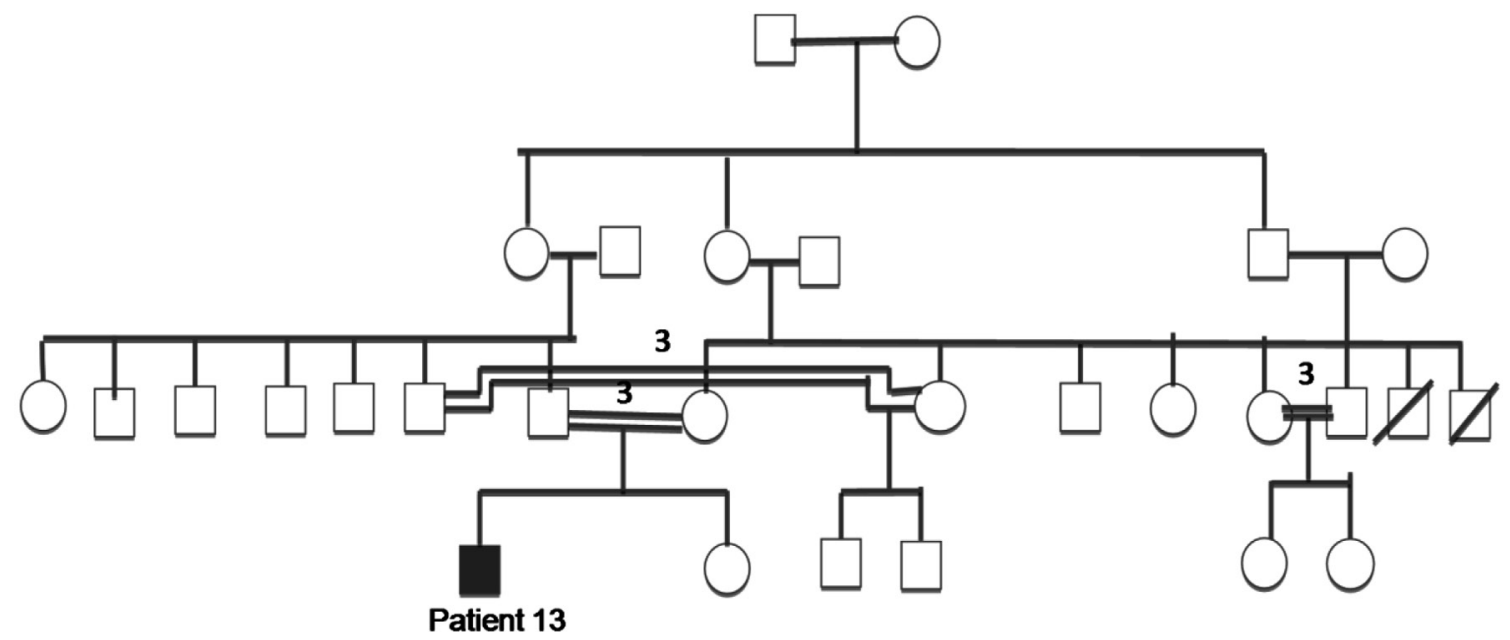

Fig. 2c. Pedigree of patient 13

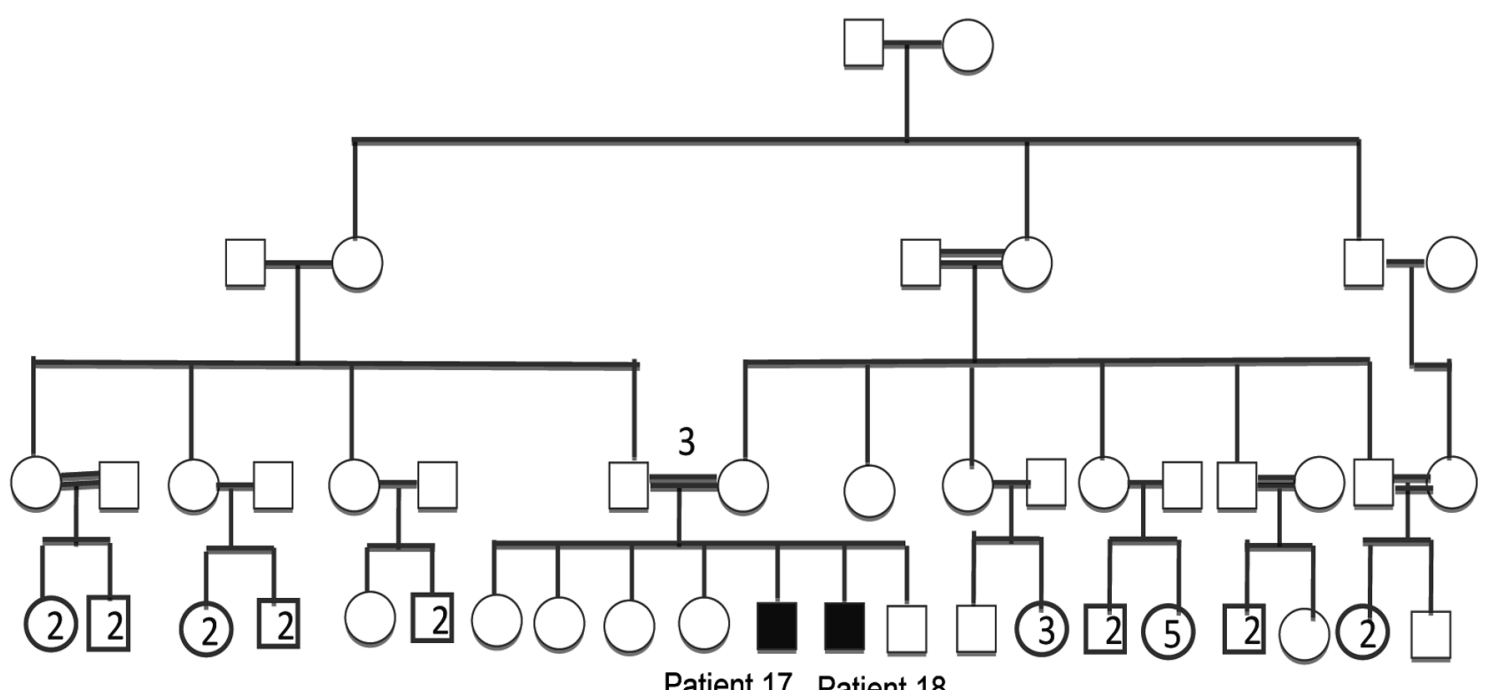

Fig. 2d. Pedigree of patients 17-18

al. ${ }^{12}$ was found as $2.5 \%$. Homozygous variants were identified in patients $2,11,12$, and 16 despite the absence of known consanguineous relationship between the partners. This may be explained by the fact that these families present with the most common type in our country, the c. $451 \mathrm{~A}>\mathrm{G}$ mutation, or that the information obtained from the families regarding the consanguineous relationship could have been inaccurate. A compound heterozygous variant was identified in patient 7 , whose parents do not have a consanguineous relationship. With regards to evaluation in terms of phenotypic properties, among 6 patients identified with a new mutation, patient 1 was on CAPD program due to end-stage renal disease (ESRF), with an aggressive clinical and severe course at the age of 10 years, and four patients with numbers $5,13,17$, and 18 were monitored as a result of their renal insufficiency (RI). Therefore, it can be concluded that the new mutation leads to a rapid progression to renal failure $(5 / 6)$ and is associated with severe clinical course, despite early diagnosis and treatment. The most common type in our study, the c.451A > G mutation, was previously described in Turkey and associated with a moderate clinical course ${ }^{16}$. Similarly, all of our patients with the c.451A $>$ G mutation $(2,3,4,10,11,12,14,16,20)$ were diagnosed between the ages of 2 to 14 years with renal tubular acidosis (RTA), excluding only one patient. Patient 16, who was on 


\section{hemodialysis program due to ESRF.}

Patient 7, who has compound heterozygous for c. $451 \mathrm{~A}>\mathrm{G}$ and c.1015G $>\mathrm{A}$, was diagnosed at age 6 months and is still being monitored for RTA. The presentation of the clinical indications in a patient identified by Topaloğlu et al. ${ }^{14}$ with a similar mutation association at early stage may indicate that these two mutations together result in a mild clinical course.

Three out of seven patients with the c.681G $>$ A mutation are on the CAPD program due to renal failure. Similarly, Topaloğlu et al. ${ }^{14}$ reported the same mutation in homozygosity in three patients with early age diagnosis and an aggressive course. This mutation was first described in Saudi Arabia and then reported as being the most common mutation, which results in an early-onset clinical course, as also shown by a study in Iran. ${ }^{15,16}$ All of these findings suggest that this mutation may be of Middle East origin and emerged in Turkey as a result of migrations from the Middle East.

Patients 15 and 24 were diagnosed early with c.18_21delGACT mutation, and are being followed for RTA at our clinic. Similarly, the studies performed in Italy and Turkey have reported that this mutation presented early indications and a slow course. ${ }^{14,17}$

Consequently, upon comparison of the patients with cystinosis in this particular region with the European and North American patients, it is clear that different CTNS variants result in this disease. Sharing of some of the mutations between the Middle East countries and Turkey is likely due to the historical and geographical proximity. However, c.451A $>\mathrm{G}$ and c.834 842 del mutations appear to be specific to the Turkish society. While c.451A $>$ G mutation is associated with a moderate clinical course, c.834 842del mutation is associated with a severe clinical course. Larger patient series are required to demonstrate the genotypic properties of the patients with cystinosis and their relationship with the clinical course.

\section{REFERENCES}

1. Gahl WA, Thoene JG, Schneider JA. Cystinosis. N Engl J Med 2002; 347: 111-121.

2. Gahl WA, Thoene J, Schneider JA. Cystinosis: a disorder of lysosomal membrane transport. In: Scriver CR, Beaudet AL, Sly WS, Valle D, Childs B, Kinzler KW, Vogelstein B. (Eds) The Metabolic and Molecular Bases of Inherited Disease 8th ed McGraw-Hill, New-York 2001; 5085-5108.

3. Bois E, Feingold, Frenay P, Briard M-L. Infantile cystinosis in France: genetics, incidence, geographic distribution. J Med Genet 1976; 13: 434-438.

4. Levtchenko EN, Van Dael CM, De Graaf-Hess AC, et al. Strict cysteamine dose regimen is required to prevent nocturnal cystine accumulation in cystinosis. Pediatr Nephrol 2006; 21: 110-113.

5. Gahl WA, Kuehl EM, Iwata F, Lindblad A, Kaiser-Kupfer MI. Corneal crystals in nephropathic cystinosis: natural history and treatment with cysteamine eyedrops. Mol Genet Metab 2000; 71: 100-120.

6. Langman CB, Moore ES, Thoene JG, Schneider JA. Renal failure in a sibship with late-onset cystinosis. J Pediatr 1985; 107: 755-756.

7. Wilmer MJ, Schoeber JP, Van den Heuvel LP, Levtchenko EN. Cystinosis: practical tools for diagnosis and treatment. Pediatr Nephrol 2011; 26: 205-215.

8. Servais A, Moriniere V, Grunfeld JP, et al. Late-onset nephropathic cystinosis: clinical presentation, outcome, and genotyping. Clin J Am Soc Nephrol 2008; 3: $27-$ 35.

9. Kimonis VE, Troendle J, Rose SR, et al. Effects of early cysteamine therapy on thyroid function and growth in nephropathic cystinosis. J Clin Endocrinol Metab 1995; 80: 3257-3261.

10. Kleta R, Bernardini I, Ueda M, et al. Long-term followup of well-treated nephropathic cystinosis patients. J Pediatr 2004; 145: 555-560.

11. Town M, Jean G, Cherqui S, et al. A novel gene encoding an integral membrane protein is mutated in nephropathic cystinosis. Nat Genet 1998; 18: 319-324.

12. Shotelersuk V, Larson D, Anikster Y, et al. CTNS mutations in an American-based population of cystinosis patients. Am J Hum Genet, 1998; 63: 1352-1362.

13. Attard M, Jean G, Forestier L, et al. Severity of phenotype in cystinosis varies with mutations in the CTNS gene: predicted effect on the model of cystinosin. Hum Mol Genet 1999; 8: 2507-2514.

14. Topaloglu R, Vilboux T, Coşkun T, et al. Genetic basis of cystinosis in Turkish patients: a single-center experience. Pediatr Nephrol 2012; 27: 115-121.

15. Shahkarami S, Galehdari H, Ahmadzadeh A, Babaahmadi M, Pedram M. The first Molecular genetics analysis of individuals suffering from nephropatic cystinosis in the Southwestern Iran. Nefrologia 2013; 33: 308-15.

16. Aldahmesh MA, Humeidan A, Almojalli HA, et al. Characterization of CTNS mutations in Arab patients with cystinosis. Ophthalmic Genet 2009; 30: 185-189.

17. Mason S, Pepe G, Dall'Amico R, et al. Mutational spectrum of the CTNS gene in Italy. Eur J Hum Genet 2003; 11: 503-508. 